\title{
PRELIMINARY OBSERVATION ON LIVING HABITS OF ACANTHASTER PL A NCI (LINNAEUS) AT PULAU TIKUS, SERIBU ISLANDS
}

\author{
by \\ AZNAM AZIZ ${ }^{1)}$ and SUKARNo 1)
}

\begin{abstract}
During the period of June 1975 to August 1975, observations on living habit and some ecological aspects of Acanthaster planci were made at Pulau Tikus, Seribu Islands. The observations, limited to 8 metres deep, were made at the outer reef located south of Pulau Tikus, covering an area of about 4000 square metres. The density of living stony corals and the damaged caused by the feeding activities of A. planci were also studied.

The results show that the average numbers of A. planci per month is 20 individuals per $4000 \mathrm{~m}^{2}$. The sizes of the starfish vary between $26-41 \mathrm{~cm}$ in diameter and the number of arms between $10-18$. The moving distance of the starfish is 0.3 - 8 metres in 24 hours.

The stony corals affected are Acropora squamosa (BROOK), A. spathulata (BROOK), A. Latistella (BROOK), A. quelchi (BROOK), Fungia sp.. Montipora ramosa BERNARD, Porites sp., DipIoria sp., and Goniatrea sp.
\end{abstract}

\section{INTRODUCTION}

Acanthaster planci (L.) is known as coral-eating starfish and its explo -sion is reported to cause serious damage to living stony corals (DEFVANEY \& RANDALL 1973; ENDEAN \& STABLUM 1973 a, b.; HAYASHI \& TATSUKI 1975; MARSH \& TSUDA 1973; RANDALL 1973 a). MORTENSEN (1931) is the first to record the presence of $A$. planci which is quite common on the coral reefs of Seribu Islands.

The study of coral reef formation at Pulau Pari group, made during the period of 1969 to 1974, showed the presence of A. planci at several places (SUKARNO 1975). Pulau Pari group lies about $35 \mathrm{~km}$ northwest off Jakarta, located at $05^{\circ} 50^{\prime} 00^{\prime \prime}$ to $05^{\circ} 52^{\prime} 25^{\prime \prime} \mathrm{S}, 106^{\circ} 34^{\prime} 30^{\prime \prime}$ to $106^{\circ} 38^{\prime} 20^{\prime \prime} \mathrm{E}$ (GoOdING 1969) (Fig. 1). The starfish is common at the outer reef, south of Pulau Tikus, very rare at other part of the outer reef, and is not found on coral patches close to the lagoon. A. planci is seen crawling over the top of living tabulate Acropora, branching A cropora, and plate Montipora. The native fishermen call this starfish "bulu-seribu" which means thousand thorns.

Observation on living habit, moving distance, relative abundance, size and number of arms, colour varieties, and position on the coral were made

1) National Institute of Oceanology, Indonesian Institute of Sciences, Jakarta, Indonesia. 
AZNAM AZIZ \& SUKARNO

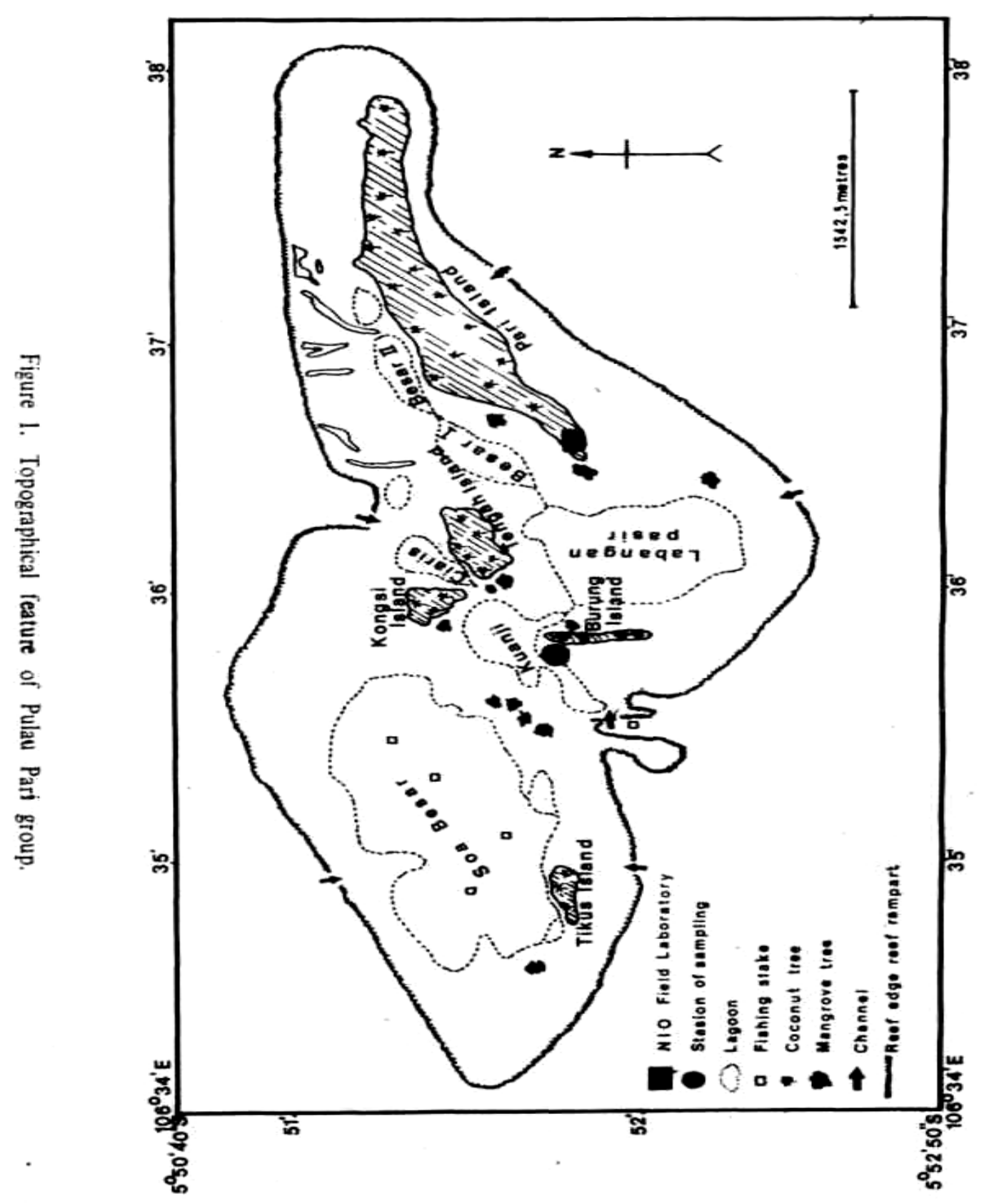


only at the reef-margin and reef-front parts of outer reef at the south of Pulau Tikus. According to GOREAU (1962) this starfish is potentially capable of moving at great distances in a single night.

\section{DESCRIPTION OF THE STUDY AREA}

The southern part of Pulau Tikus is a sandy plateau, which is a part of the reef-flat zone. It is followed by reef-margin zone, reef-front zone, and seaward slope (Fig. 2). The reef zonation follows the system used by RANDALL (1973 b).

The reef-flat zone is about 200 metres wide measured from the lowest water line up to the end of reef rampart. The reef flat which is composed of limestone flatform is covered with coral rubbles and sand. The reef-flat zone is divided into two sub-zones, the "Enhalus-bed" at the innter part and the "Sargassum-bed" at the outer part. The "Enhalus-bed" is about 120 metres wide while the "Sargassum-bed" is only about 60 metres wide. The floor of this bed is sandy. Diadema setosum are quite abundance in this subzone and are found in small groups consisting of 5 - 20 individuals. The floor of the "Sargassum-bed" is sandy with rubbles on it and inhabited by Culcita, Linckia laevigata, and some holothurians. The reef rampart, which is a part of the outer reef flat, has a total width of 10 - 20 metres, and is mostly covered by A cropora plateau. It is exposed at low tide.

The reef margin is represented by the seaward edge of the reef-flat platform that is constantly washed even at low tide. The reef margin varies in width from 10 to 15 metres along outer reef of Pulau Tikus and in depth from 1 to. 3 metres. The floor of the reef margin is coral boulders and rubbles. The stony corals are represented by tabulate Acropora, Hydnopora, branching Acropora, plate Montipora, Fungia, Porites, Pocillopora, Diplo-ria, Goniastrea, and Psammocora. At the eastern part, the reef margin is cut by a channel. The bottom of the channel is dominated by tabulate Acropora and has denser coral formation. The echinoderms at this zone are represented by holothurians, starfishes (Linckia, Nardoa, and Fromia), echinoids (Echinometra, Diadema), and ophiuroids.

The reef-front zone represents the extreme seaward edge of the reef platform, where the reef margin abruptly increases in depth and in degree of slope. At the outer reef, south of Pulau Tikus, the reef-front zone varies in width from 5 to 10 metres and from 1 to 8 metres in depth. The reef-front zone, then connected with that of the seaward slope zone, has its floor covered by dead coral, coral boulders, and rubbles. The stony corals are represented by huge Porites (about 1-2 metres in diameter), branching Acropora, Pocillopora, plate Montipora, and Millepora. Beside stony corals, alcyonarians, sea anemones, gorgonarians, and antipatharians are also found inhabiting the reef front and reef margin zones. Algae are represented by 
AZnAM Aziz \& SUKARNO

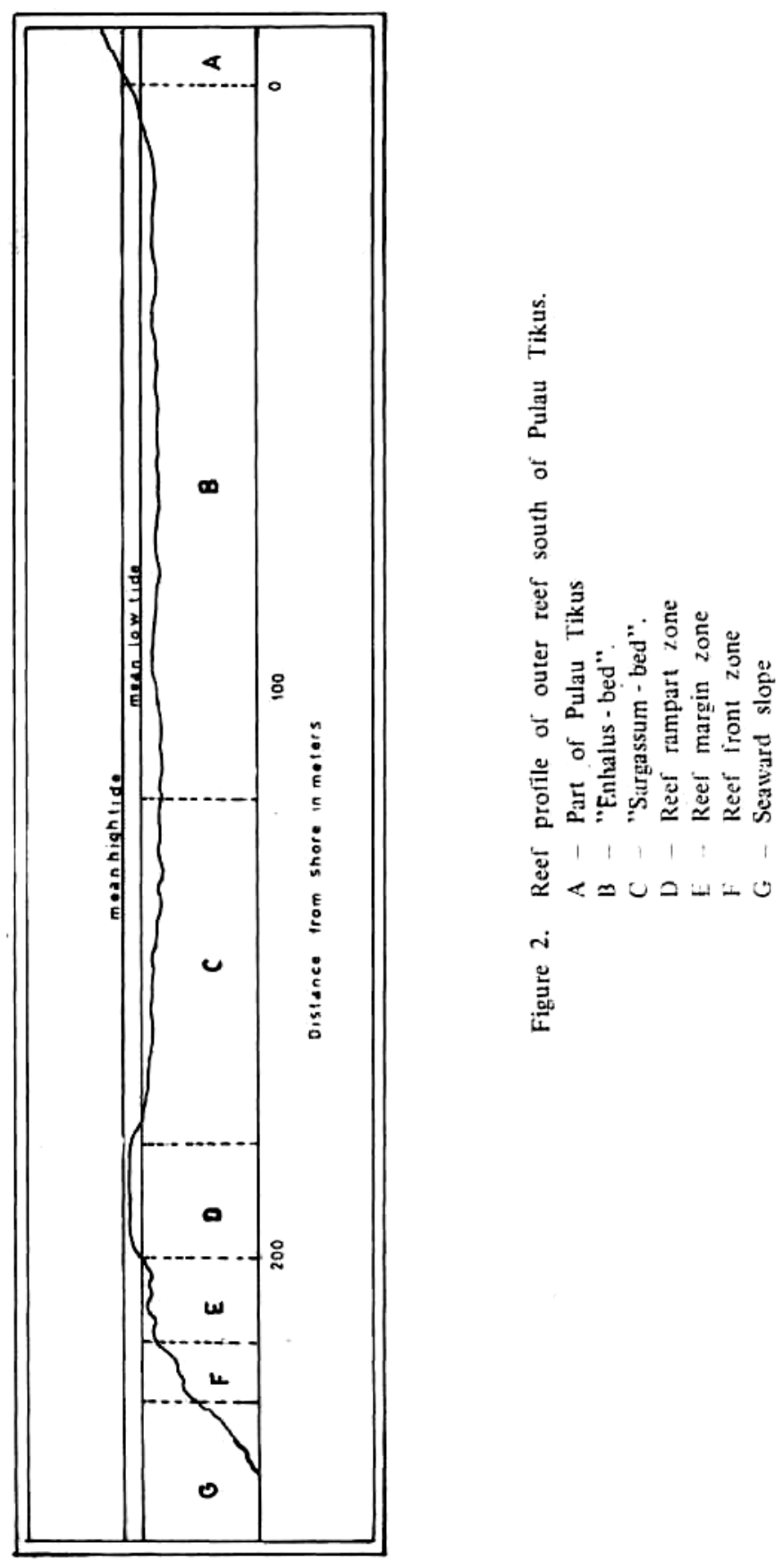


Halimeda, Caulerpa, Laurencia, and Galaxaura. Echinoderms, besides A. planci are represented by starfishes (Linckia, Fromia), and crinoids such as Comanthus, Comantheria, Ptasometra, and Stephanometra which are found especially at the seaward side of the reef front.

\section{MATERIALS AND METHODS}

Observations of living habits of A. planci were made during the periods of June to August 1975 at the reef-margin zone and reef-front zone, south of Pulau Tikus. The observation area covers the edge of the reef rampart up to the seaward edge of reef front (about 20 metres wide and 200 metres long) (Fig. 3). A. planci is always observed to inhabit this area throughout the whole year.

Observations were done by snorkelling, two days each month. The moving distance of each animals within 24 hours was recorded firstly by identifying individual starfish according to its individual characteristics, such as colour varieties, number of arms, and size. Then the position of each starfish was marked and distance was measured after 24 hours. In order to avoid the possibility of counting an individual more than once, a plastic cap with number or code was placed beside each starfish as it was found. This method is adopted from MEYER (1973) (on crinoid at Ca-ribia). In this observation the term "exposed" is used for animals oh the surface of substrate and "unexposed" for those who are hiding or covered. Size is measured from tip of arm to tip of opposite arm. Relative population density is the mean number of individual recorded in the observed area.

Area of observation is divided into 30 squares. At each corner of the square, a frame of $1 \mathrm{X} 1$ metres is placed. Percentage cover of stony corals is estimated by counting the mean percentage of stony corals inside the frame.

Recently killed corals are recognized by their stark white skeletons. Estimates of percentage of coral damaged by feeding activities of A planci, were done by measuring white spots of stony coral in situ. Samples of damaged coral were taken to the laboratory for identification.

\section{RESULTS}

The moving distance of Acanthaster planci in 24 hours varies between 0.3 to 8 metres. The relative population density of $A$. planci is 20 individual starfishes per 4000 square metres. The size of starfish varies between 26 to 41 centimetres. The number of arms varies between 10 to 18. The percentage of coral cover is $13.9 \%$ (Table IV). The percentage of damaged coral caused by feeding activities of Acanthaster planci during observation is about $0.37 \%$ (Table V). 
AZNAM Aziz \& SUKARNO

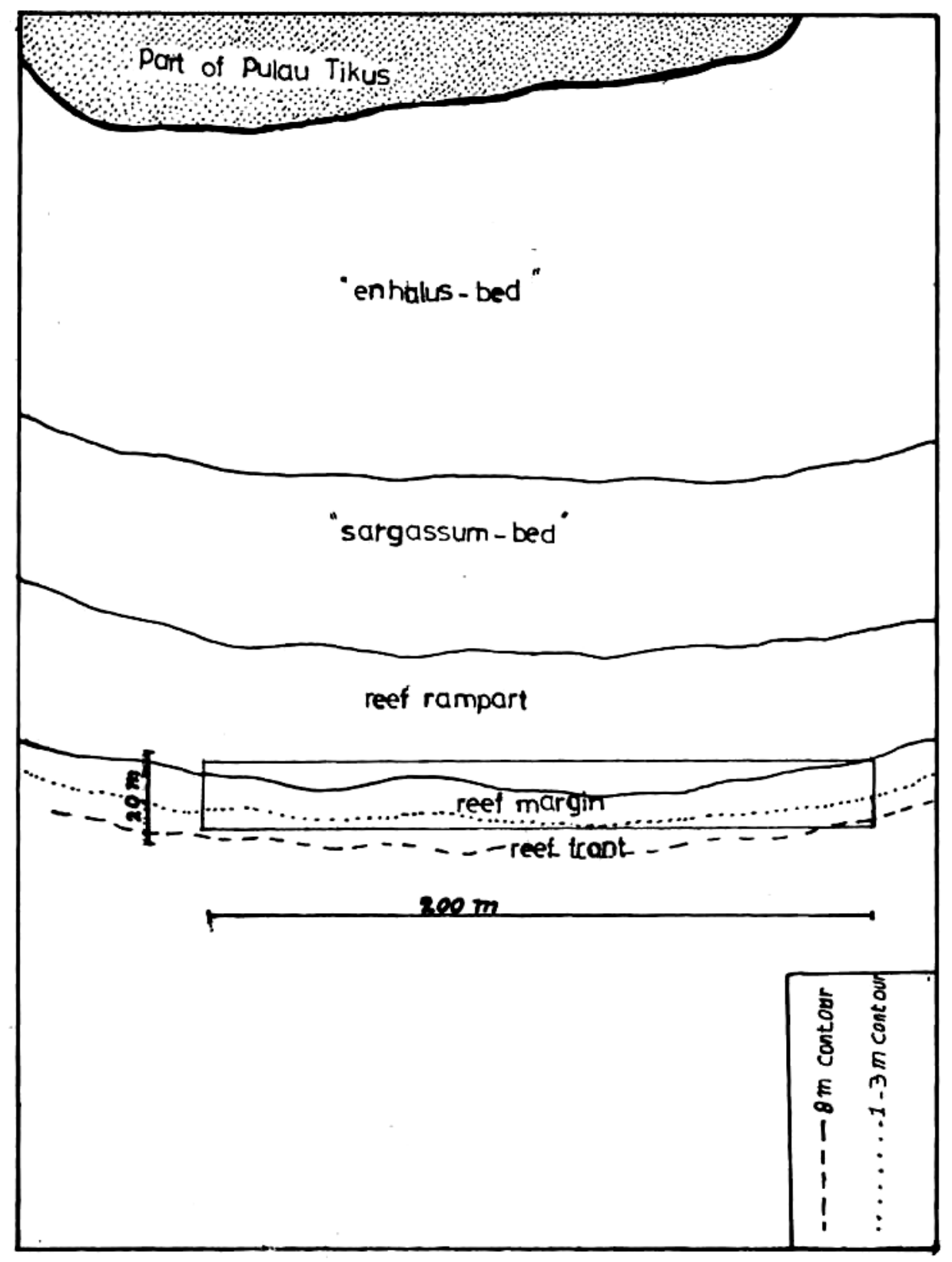

Figure 3. Detail map of transect location 
The species of stony corals damaged are Acropora squamosa (BROOK ), A. spathulata (BRoOK), A. quelchi (BRoOK), Fungia sp., Montipora ra-mosa BERNARD, Porites sp , Diploria sp, and Goniastrea sp.

\section{DISCUSSION}

Acanthaster planci (L.) is rarely found around Pulau Pari group. This starfish lives only at outer reef which surrounds Pulau Pari group, especially south of Pulau Tikus. At coral patches in the lagoon of Pulau Pari group it was never seen. In the daytime it retreats into a dark crevice where it stays immobile, and feeding takes place mostly at night (GOREAU 1964). At the south of Pulau Tikus, it exposes on the top of stony coral or unexposes especially under the tabulate Acropora (Tables I, II, III). Acanthaster planci, in study area, is never seen in aggregation.

The moving distance of this starfish varies between 0.3 to 8 metres in 24 hours. It moves from one prey to another. According to GOREAU (1964), on the bare sand, it moved between 5 to 10 metres per hour. From the observation it is known that the starfish moves especially from reef margin to reef rampart (Tables I, II, III), and this movement may be due to feeding activities or caused by wave action. Some starfishes stay immobile after 24 hours. At reef rampart, Acropora, especially tabulate Acropora, is predominant stony coral. Acropora might be prefered by this starfish (GOREAU et al 1972). Other stony coral prefered by A. planci are Monti-pora (at Saipan) and Pocillopora (at Panama). During the observation at the outer reef, south of Pulau Tikus, Pocillopora is not preyed by this starfish.

Acanthaster planci, at the south of outer reef of Pulau Tikus shows colour variations; they are grey, purple, reddish-grey, and intermediate form. According to MORTENSEN (1931) these colour variations are evidently only individual. Number of arms of A. planci varies from 10 to 18, and the size varies from 16 to 42 centimetres. On this observation, the juvenile stage was never seen.

The mean relative population density of A. planci was 20 individuals per 4000 square metres. At Pulau Pari group it might be the highest, because at the south outer reef of Pulau Tikus the population of A. planci is greater than the other parts.

Damages of stony corals are caused by the accumulation of some factors such as man activities, wave action, and activities of feeding habit of $A$. planci. Estimate of coral damages by feeding activities of. A. planci at outer reef south of Pulau Tikus is about $0.37 \%$, and it is relatively low. The feeding activities of $A$. planci do not cause serious effect on reef communities. Man activities, such as collecting corals for road and house constructions or for decorations, besides the native fisherman who dig corals for Trochus, 
AZNAM AZIZ \& SUKARNO

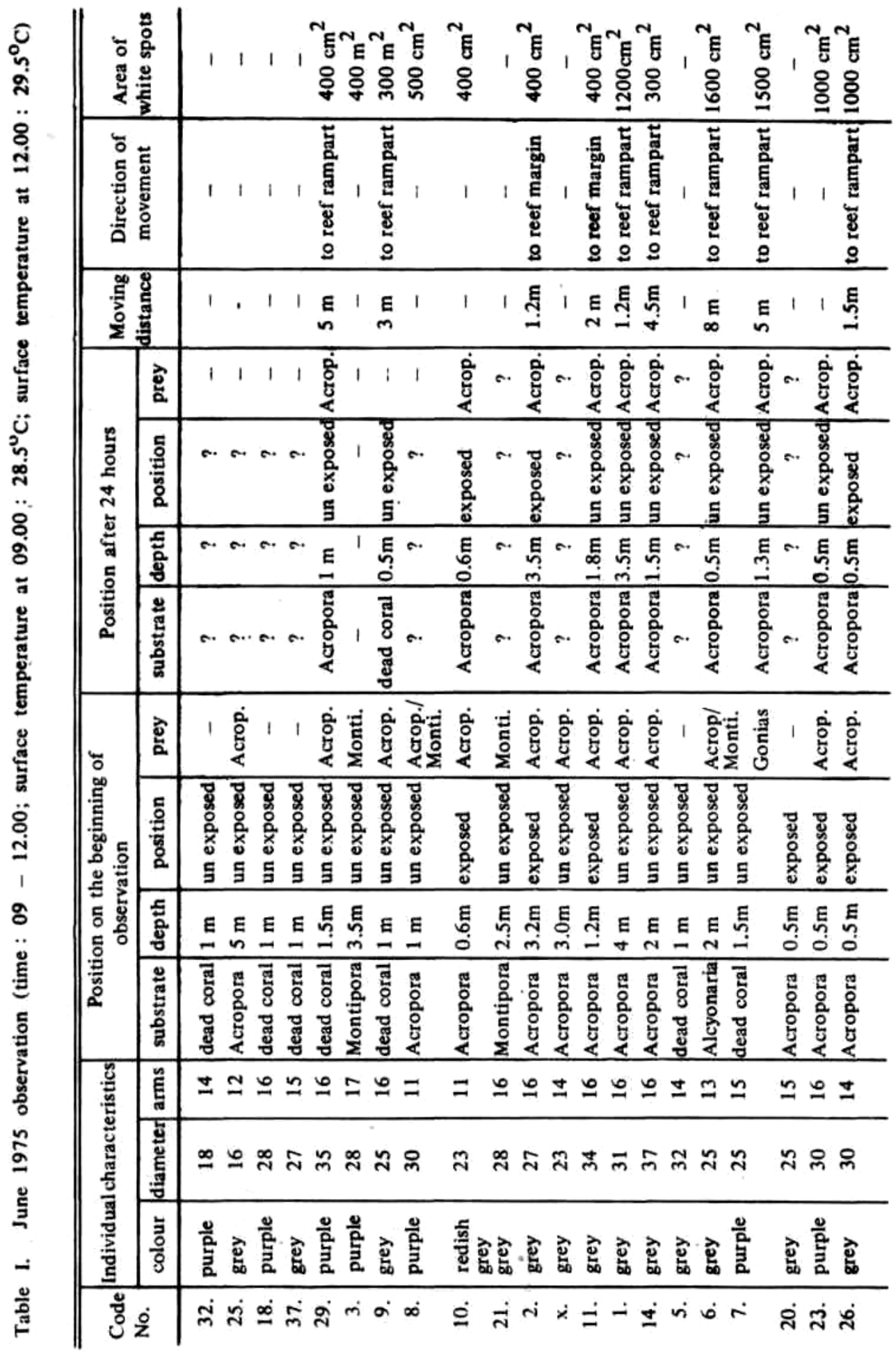


PRELIMINARY OBSERVATION ON LIVING HABITS

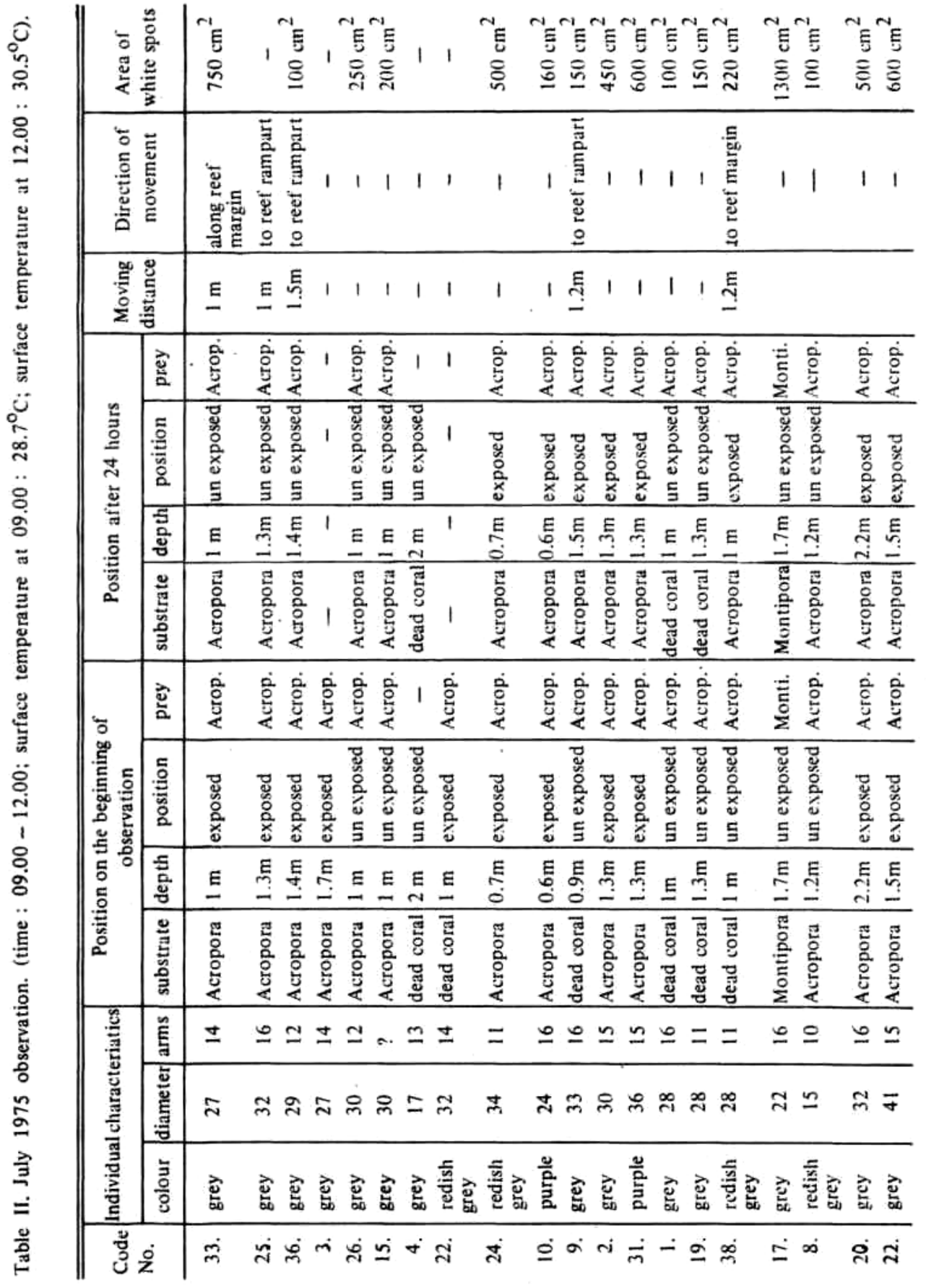


AZNAM AZIZ \& SUKarno

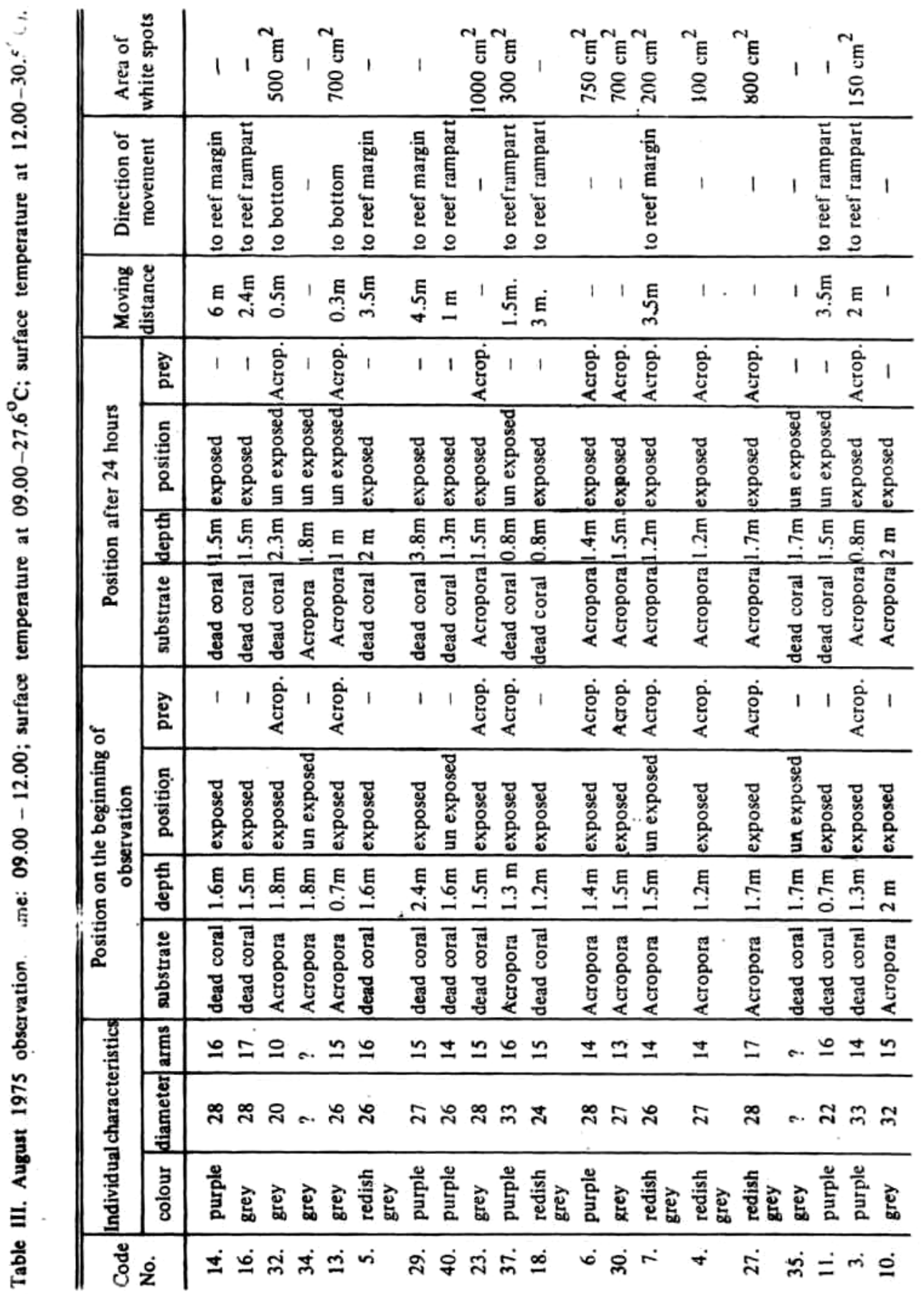




\section{PRELIMINARY OBSERVATION ON LIVING HABITS}

Table IV. Percentages of coral cover on the outer reef south of Pulau Tikus.

$$
\begin{array}{lll}
\text { Total square } & : & 4000 \mathrm{~m}^{2} \\
\text { Depth } & : & 0.2 \text { to } 8 \mathrm{~m} . \\
\text { Date } & : & \text { July } 29 \quad 1975 .
\end{array}
$$

\begin{tabular}{|c|c|c|c|c|c|c|}
\hline$\underbrace{\text { no. frames } y}_{\text {no. frames } x}$ & $\begin{array}{c}\text { I } \\
\mathrm{cm}^{2}\end{array}$ & $\begin{array}{c}\mathrm{Il} \\
\mathrm{cm}^{2} \\
\end{array}$ & $\begin{array}{l}\text { III } \\
\mathrm{cm}^{2}\end{array}$ & $\begin{array}{l}\text { IV } \\
\mathrm{cm}^{2}\end{array}$ & $\begin{array}{l}\mathrm{V} \\
\mathrm{cm}^{2}\end{array}$ & $\begin{array}{r}\mathrm{VI} \\
\mathrm{cm}^{2} \\
\end{array}$ \\
\hline 1. & 0 & 900 & 0 & 400 & 2125 & 225 \\
\hline 2. & 1800 & 2700 & 150 & 550 & 1800 & 850 \\
\hline 3. & 450 & 675 & 3150 & 0 & 1125 & 1575 \\
\hline 4. & 1800 & 225 & 2475 & 2250 & 3600 & 2475 \\
\hline 5. & 3150 & 900. & 1575 & 3600 & 675 & 450 \\
\hline $\begin{array}{l}\text { Total square frames of } \\
\text { each quadrat }(\mathrm{cm}) .\end{array}$ & 7200 & 5400 & 7350 & 6800 & 9325 & 5575 \\
\hline $\begin{array}{l}\text { Percentage of each quadrat } \\
\text { per total area. }\end{array}$ & 14.4 & 10.8 & 14.7 & 13.6 & 18.65 & 11.15 \\
\hline $\begin{array}{l}\text { Mean percentage of coral } \\
\text { cover }\end{array}$ & \multicolumn{6}{|c|}{$13.9 \%$} \\
\hline
\end{tabular}

Table V. Estimation of coral damage by feeding activities of $A$. planci.

\begin{tabular}{|c|c|}
\hline Month & Area of monthly coral damage in $\mathrm{cm}^{2}$ \\
\hline June & 9400 \\
\hline July & 6130 \\
\hline \multicolumn{1}{|c|}{ August } & 5200 \\
\hline $\begin{array}{l}\text { Total of coral } \\
\text { daınages in cm } 2\end{array}$ & 20730 \\
\hline $\begin{array}{l}\text { Percentage of damaged coral } \\
\text { during observation }\end{array}$ \\
\hline
\end{tabular}




\section{AZNAM AZIZ \& SUKARNO}

Tridacna, and Lambis will cause really serious damage to the coral communities.

During the observation the corals which are affected by the feeding activities of $A$. planci are Acropora squamosa (BROOK), A. spathulata (BrooK), A. latistella (BrooK), A. quelchi (BrooK), Fungia sp.,Montipora ramosa BERnARD, Porites sp., Diploria sp., and Goniastrea sp. This starfish is never seen crawling on the top of Millepora coral and probably avoiding this group. The same case is also seen at Great Barrier Reef, it avoids Millepora coral (ENDEAN \& STABLUM 1973).

\section{ACKNOWLEDGEMENT.}

The authors are deeply indepted to Dr. Aprilani Soegiarto, the Director of the National Institute of Oceanology, for his encouragement in this study. Thanks are offered to Mr. M. KASIM MoosA for his correction and to Mr. NURACHMAD et al. for their technical assistance.

\section{REFERENCES}

DEVANEY, D.M. and J.E. RANDALL 1973. Investigations of Acanthaster planci in Southeastern Polynesia during 1970 - 1971. Atoll Res. Bull. 169 : 1 - 23.

ENDEAN, R. and W. STABLUM 1973a. A study of some aspects of the crown-of-thorns starfish (Acanthaster planci) infestations of reef of Australia's Great Barrier Reef. Atoll Res. Bull. $167: 1$ - 62.

ENDEAN, R. and W. STABLUM 1973b. The apparent extent of recorvery of reefs of Australia's Great Barrier Reef devasted by the crown-of-thorns starfish. Atoll Res. Bull. 168: 1 26.

GOODING, R.U. 1969. Report on Preliminary Survey of the Pulau Pari group, (unpublished). GOREAU, T.F. 1964. On predation of coral by the spiny starfish Acanthaster pjanci (L.) in Southern Red Sea. Sea Fish. Res. Stat. Haifa, Bull. 35 : 23.

GOREAU, T.F., J.C. LANG, E.A. GRAHAM, and P.D. GOREAU 1972. Structure and ecology of the Saipan reefs in relation to predation by Acanthaster planci (L.). Bull. Mar. Sci.Florida 22(1): 113.

HAYASHI, K. and T. TATSUKI 1975. Acanthaster planci plague in Japan. Bull. Mar. Park. Res. Stat., Khushimoto 1(1): 11 - 17.

MARSH, A.J. Jr. and R.T. TSUDA 1973. Population levels of Acanthaster planci in the Mariana and Caroline Islands 1969 - 1972. Atoll Res. Bull. 170 : 1 - 16.

MEYER, D.L. 1973. Distribution and living habits of comatulid crinoids near Discovery Bay, Jamaica. Bull. Mar. Set, Florida 23(2) : 244.

MORTENSEN, Th. 1931. Contributions to the study of larval forms of Echinoderms. Kobenhavn, Andr. Fred. Host \& Son . 1 - 39.

RANDALL, R.H. 1973a. Distribution of corals after Acanthaster planci (L.) investation at Tanguison Point, Guam. Micronesica J. Un. Guam 9(2) : 213.

RANDALL, R.H. 1973b. Reef physiography and distribution on coral at Tumon Bay, Guam, before crown-of-thorns starfish Acanthaster planci (L.) predation. Micronesica J. Un. Guam, 9(1): 119.

SUKARNO 1975. Penelitian pendahuluan tentang kepadatan karang batu di terumbu karang Pulau Ayer, Laut Jawa. (unpublished). 